\title{
Pharmacological therapy of osteoporosis with bisphosphonates - for whom, what kind, and for how long?
}

\author{
Leczenie farmakologiczne osteoporozy z wykorzystaniem bisfosfonianów - \\ dla kogo, jakie, jak długo?
}

\author{
Ewa Marcinowska-Suchowierska, Magdalena Walicka \\ Department of Family Medicine, Internal Medicine and Metabolic Bone Disease, Postgraduate Medical Education Center, Warsaw, Poland
}

Key words: osteoporosis, bisphosphonates, drug safety.

Słowa kluczowe: osteoporoza, bisfosfoniany, bezpieczeństwo terapii.

\begin{abstract}
Sum mary
For many years bisphosphonates (BS) have played an important role in the treatment of postmenopausal osteoporosis. Additionally, they have recently been used in men and induced osteoporosis by administering glucocorticoids and some other secondary osteoporosis. Designing pharmacologically equivalent BS substance administered orally once a week or once a month allowed to reduce side effects related to the digestive system. Availability of intravenous BS substance resulted in a more frequent occurrence of the acute phase reactions. Recently a relation has been noticed between the use of BS and the occurrence of complications including osteonecrosis of the jaw and atypical subtrochanteric fractures. In this article the authors present current knowledge regarding BS treatment in osteoporosis and some adverse effects related to its long-term use. This information will help to optimize the length of treatment with BS and to make a decision about potential discontinuation of BS treatment.
\end{abstract}

\section{Introduction}

Osteoporosis is a systemic skeletal disease characterized by an increased risk of fractures due to reduced bone resilience resulting from low mineral density and bone tissue quality. Osteoporosis manifests clinically with low-energy fractures either resulting from minor trauma (a fall from standing height) or occurring spontaneously (with no trauma, e.g. following a sneeze).

\section{Streszczenie}

Bisfosfoniany (BS) od wielu lat odgrywają istotną rolę w leczeniu osteoporozy pomenopauzalnej. W ostatnim czasie faktem stały się również wskazania do ich stosowania u mężczyzn oraz w osteoporozie indukowanej podawaniem glikokortykosteroidów i w niektórych innych osteoporozach wtórnych. Opracowanie doustnych preparatów BS podawanych raz na tydzień lub raz w miesiącu pozwoliło zmniejszyć częstość objawów niepożądanych ze strony przewodu pokarmowego. Dostępność preparatów dożylnych BS umożliwiła wyeliminowanie objawów niepożądanych dotyczących przewodu pokarmowego, jednak kosztem częstszych reakcji ostrej fazy. Obserwacje z ostatnich lat wskazały na związek pomiędzy stosowaniem bisfosfonianów a występowaniem takich powikłań, jak martwica żuchwy czy złamania podkrętarzowe, co wywołało zainteresowanie bezpieczeństwem ich powszechnego i długoterminowego stosowania. W artykule podsumowano aktualny stan wiedzy o znaczeniu BS w leczeniu osteoporozy oraz działaniach niepożądanych w czasie ich wieloletniego stosowania, co utatwi optymalizację czasu leczenia BS oraz podjęcie decyzji o ewentualnej przerwie w ich podaży u danego pacjenta.

The goal of osteoporosis treatment is fracture prevention: primary - in those with no previous fractures, and secondary - in those who have already suffered one or more fractures.

Treatment should be administered to those with a 10-year absolute risk of osteoporotic fractures (AR-10) higher than that in the general population. The 10-year absolute risk of vertebral, proximal femoral (hip), fore-

Address for correspondence:

Prof. Ewa Marcinowska-Suchowierska, MD, PhD, DSc, Department of Family Medicine, Internal Medicine and Metabolic Bone Disease, Postgraduate Medical Education Center, Czerniakowska 231, 00-416 Warsaw, Poland, e-mail: ewa.marcinowska@w.pl Submitted: 11.02 .2014 
arm or humeral fractures in treatment-naïve postmenopausal women and men over 50 years old can be estimated via the World Health Organization's (WHO) absolute fracture risk model FRAX. This model combines multiple clinical parameters affecting fracture risk [age, gender, body mass index (BMI), prior low-energy fracture, parental history of hip fracture, current smoking, alcohol consumption, prolonged (> 3-month) glucocorticoid (GC) use, rheumatoid arthritis (RA)] and femoral neck bone mineral density (BMD). The threshold for medical intervention is established by various expert groups based on data for the given population and economic situation of the given country [1].

According to Polish osteoporosis experts, a high AR-10 rate, i.e. over $10 \%$, requires the use of medical treatment irrespective of BMD. With a moderate fracture risk (AR-10 between $5 \%$ and $10 \%$ ) the result of BMD assessment is necessary to make therapeutic decisions, since a low BMD ( $T$-score $<-2.5 \mathrm{SD}$ ) in this group of patients may increase the risk of fracture beyond $10 \%$, consequently indicating the need for treatment. On the other hand, a normal BMD value suggests only prophylactic actions (healthy life style, fall prevention, and improving general fitness level) [2].

Previous studies indicate that an osteoporotic fracture, even with normal BMD, is a BMD-independent predictor of subsequent fractures. Therefore, a history of fracture automatically places the patient in a high-risk group. This means that medical treatment in osteoporosis should be used in everyone with a history of fracture following a minor trauma, especially vertebral, forearm, or hip fracture (regardless of BMD). Moreover, prolonged (> 3 months) use of GCs (prednisone at $\geq 5 \mathrm{mg} /$ day or equivalent dose of another GC) increases the preexisting fracture risk by one level (from low to moderate, from moderate to high). Additionally, the FRAX model is not useful in predicting the fracture risk in individuals below 50 .

Consequently, medical treatment of osteoporosis should be recommended in people with a high (>10\%) AR-10 and a previous low-energy fracture. The choice of medication is always left to the physician's discretion $[2,3]$.

The physician's decision on drug selection should be based on the general clinical assessment, medical indications for the given drug (regulatory statements based on multicenter randomized double-blind placebo-controlled clinical trials (RCTs) demonstrating the drug's efficacy in preventing new fractures), as well as the drug's known side effects. Knowing these facts, the physician selects medications, bearing in mind the safety, antifracture efficacy, therapeutic benefits for other tissues and organs, drug's tolerance and the patient's acceptance of the selected drug, expected compliance, and the patient's ability to take the drug and continue treatment.
Medical treatment for osteoporosis affects the fundamental processes of bone remodeling, i.e. bone resorption (antiresorptive agents), bone formation (anabolic agents), or both (mixed-action anabolic/antiresorptive agents). Previous studies demonstrated antifracture effects of antiresorptive agents (bisphosphonates, denosumab, raloxifene) only in people with low bone mass (T-score $\leq-2.5 \mathrm{SD}$ ), whereas anabolic agents (teriparatide) and mixed action agents (strontium ranelate) successfully prevented osteoporotic fractures, irrespective of initial BMD values.

Bisphosphonates (BPs) are a group of chemical agents of known antiresorptive and antifracture efficacy that have played an important role in the treatment of skeletal conditions and bone metabolism abnormalities for over 30 years. These last three decades have seen not only alterations to BP structure (side-chain configuration, which improved their antiresorptive efficacy), but also generating such forms of BPs that allow for their administration not daily, but rather once a week or once a month, which facilitates treatment continuation. Intravenous forms of the drug have allowed for effective bisphosphonate treatment in patients with gastrointestinal contraindications for oral therapy. Therefore, it is not surprising that BPs are typically drugs of choice for patients with low bone mass and are currently believed to be the "golden standard" of antifracture treatment in postmenopausal women, in men, and in patients with glucocorticoid-induced osteoporosis (GIO) alike [3, 4].

Nonetheless, it must be emphasized that the more and more prolonged use of BPs in osteoporosis treatment, apart from confirming the antifracture efficacy, also provides new information on the drugs' less than beneficial effects, both skeletal and extra-skeletal. This fact should be always considered when choosing BPS for osteoporosis treatment in each patient and must not be overlooked in patients receiving long-term BP treatment. The following material was meant to facilitate a better understanding of not only the target patient populations for whom BPs should be chosen, how to select the drug, but also how long such treatment can be safely continued in a given patient.

\section{Bisphosphonates \\ Background}

Bisphosphonates are synthetic analogs of naturally occurring pyrophosphate (P-O-P) compounds, where the oxygen atom is replaced with a carbon atom (P-C-P). The addition of two side-chains (substituents) or a hydroxyl group (R1) to the carbon atom increases BP affinity to hydroxyapatite crystals, whereas an addition of nitrogen or amine groups (R2) determines the antiresorptive potency of BPs (Fig. 1). 
Bisphosphonates may be classified into 3 groups based on the structure of their R2 side-chains:

- non-nitrogen-containing BPs (etidronate, clodronate, tiludronate),

- nitrogen-containing alkyl-amino-BPs (pamidronate, alendronate, ibandronate),

- BPs with nitrogen-containing heterocyclic rings (risedronate, zoledronate).

Bisphosphonates action is mainly limited to bones due to the high affinity of these drugs to hydroxyapatite, their resistance to hydrolysis, and very long duration of effects (BPs can remain active in bone tissue for years).

\section{Mechanism of action}

The BP mechanism of action depends on the drugs' chemical structure (Fig. 1). All BPs bind with hydroxyapatite on the surface of bones (forming complexes resistant to enzymatic, chemical or physical hydrolysis) and effectively inhibit bone formation. This fundamental property of BPs has been the basis of their clinical use (following the necessary modifications to their chemical structure).

The anchor-like binding of BPs to the bone matrix is due to their P-C-P structure, but it is also associated with the presence of a hydroxyl group or Cl (R1). The structure and special configuration of the side chains (R1 and R2) determines biological activity of BPs in inhibiting bone resorption via the drugs' interactions with molecules taking part in bone tissue metabolism (Fig. 1, Table I). Following their uptake via endocytosis into osteoclast cytosol, simple BPs (i.e. those with small side-chain size) inhibit several key enzymes associated with bone resorption and induce osteoclast apoptosis, whereas nitrogen-containing BPs, taken up by osteoclasts via endocytosis, bind to farnesyl pyrophosphate synthase and inhibit its activity, which leads to cytoskeletal reorganization in osteoclasts, which results in a subsequent loss of the cells' bone-resorptive properties and, eventually, to apoptosis. The presence of nitrogen or amine groups increases the antiresorptive properties of new BPS

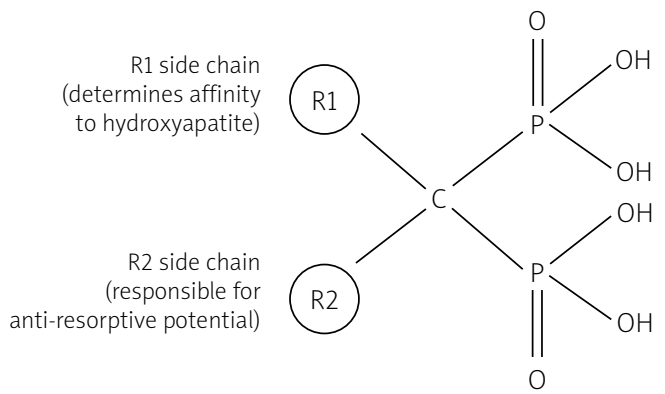

Fig. 1. Chemical structure of bisphosphonates. 10,000-to-20,000-fold in comparison to those demonstrated by earlier drugs of this group (non-nitrogen-containing BPs, such as etidronate) without any inhibitory effect on hydroxyapatite crystallization. This means that antiresorptive doses of BPs should not disrupt bone mineralization $[5,6]$.

Bisphosphonates-induced osteoclast apoptosis cannot be measured directly in a clinical setting. Thus, the use of indirect (substitute) markers, i.e. markers of bone resorption (serum and urine levels of type I collagen degradation products) helped establish that, once treatment with oral nitrogen-containing BPs is initiated, the maximum inhibition of bone resorption is achieved after approximately 3 months and remains relatively constant as the treatment continues. It is worth mentioning that bone resorption inhibition is achieved faster following intravenous BP administration than following oral administration [7].

Therefore, pharmacodynamic effects of BPs involve mainly inhibition of osteoclast-mediated bone resorption, and the potency of antiresorptive effect is determined by the structure of the R2 side chain at the central carbon atom.

\section{Gastrointestinal absorption}

All BPs are highly hydrophilic, which makes them poorly absorbable in the gastrointestinal tract following oral administration (only 1-3\% of the administered dose). Only $50 \%$ of the absorbed drug is selectively re-

Table I. Bisphosphonate structures (side chains) and the drugs' relative potency in inhibiting bone resorption

\begin{tabular}{|c|c|c|c|}
\hline $\begin{array}{l}\text { Active } \\
\text { ingredient }\end{array}$ & $\begin{array}{c}\mathrm{R} 1 \\
\text { side chain }\end{array}$ & $\begin{array}{c}\mathrm{R} 2 \\
\text { side chain }\end{array}$ & Potency \\
\hline Etidronate & $-\mathrm{OH}$ & $-\mathrm{CH}_{3}$ & $1 \times$ \\
\hline Clodronate & $-\mathrm{Cl}$ & $-\mathrm{Cl}$ & $10 x$ \\
\hline Pamidronate & $-\mathrm{OH}$ & $-\mathrm{CH}_{2}-\mathrm{CH}_{2}-\mathrm{NH}_{2}$ & $100 \times$ \\
\hline Alendronate & $-\mathrm{OH}$ & $-\mathrm{CH}_{2}-\mathrm{CH}_{2}-\mathrm{CH}_{2}-\mathrm{NH}_{2}$ & $1,000 \times$ \\
\hline Risedronate & $-\mathrm{OH}$ & N & $10,000 x$ \\
\hline Ibandronate & $-\mathrm{OH}$ & $\begin{array}{c}-\mathrm{CH}_{2}-\mathrm{CH}_{2}-\mathrm{N}\left(\mathrm{CH}_{3}\right) \\
-\left(\mathrm{CH}_{2}\right)_{4}-\mathrm{CH}_{3}\end{array}$ & $10,000 \times$ \\
\hline Zoledronate & $-\mathrm{OH}$ & $-\mathrm{CH}_{2}$ & $20,000 x$ \\
\hline
\end{tabular}


tained in the skeletal system, the rest is excreted unchanged with urine or feces. BP absorption is additionally inhibited if the drugs are taken together with food, especially that is rich in calcium or other divalent cations leading to chelation in the gastrointestinal lumen. It needs to be emphasized that this lowers their effectiveness and, consequently, treatment efficacy. Thus, it is imperative for oral BPs to be taken without food (with pure, decalcified, boiled water). Additionally, BPs are a local irritant to the upper gastrointestinal tract, especially to the esophagus. Therefore, BPs must not be chewed or sucked on, but swallowed whole instead, with the patient maintaining upright position (sitting or standing) for 30 minutes after tablet ingestion. Inability to maintain upright position, hiatal hernia, reflux esophagitis, and active peptic ulcer disease are contraindications to oral BP administration [3, 7].

Intravenous BPS (ibandronate, zoledronate) are a novel therapeutic option for osteoporosis treatment in the case of oral BP intolerance or concomitant absorption anomalies. Intravenous BP administration ensures total bioavailability, improves patients' compliance due to longer time intervals between consecutive doses, requires drug administration to be assisted by another person, and ensures the patients' more frequent contact with their treatment center.

\section{Excretion by kidneys}

Bisphosphonates are not metabolized in the body. Approximately $27-62 \%$ of the drug is bound to the bone matrix, the remainder is excreted by kidneys both via passive glomerular filtration and active secretion in the proximal tubules. Because of their pharmacokinetics, $\mathrm{BPs}$ are not recommended in patients with creatinine clearance $(\mathrm{CrCl})<35 \mathrm{ml} / \mathrm{min}$ (alendronate) or $<30 \mathrm{ml} /$ min (risedronate, ibandronate, zoledronate). Nephrotoxicity reports associated with first-generation BP and zoledronic acid relate to the use of these drugs in much higher doses than those used in osteoporosis, as well as

Table II. Bisphosphonate efficacy in reducing the risk of osteoporotic fractures in postmenopausal women (stratified by location)

\begin{tabular}{|lccc|}
\hline Bisphosphonates & Vertebral & $\begin{array}{c}\text { Femoral } \\
\text { (proximal) }\end{array}$ & $\begin{array}{c}\text { Extra- } \\
\text { vertebral }\end{array}$ \\
\hline Alendronate & + & + & + \\
\hline Risedronate & + & $+^{\mathrm{a}}$ & \\
\hline Ibandronate & + & & $++^{\mathrm{a}}$ \\
\hline Zoledronic acid & + & + & + \\
\hline $\begin{array}{l}\text { a-in a high-risk group } \\
\text { Ib }\end{array}$ & & & \\
\hline
\end{tabular}

their use in patients with neoplastic diseases (higher risk of renal complications). Reviews of clinical studies on renal complications associated with the use of BPs in osteoporotic patients with concomitant chronic renal disease suggest a good long-term safety profile of these drugs, provided that they are administered with adequate consideration of their GFR-related contraindications, which helps optimize the risk-to-benefit ratio [7, 8].

\section{Characteristics of individual bisphosphonates}

The following bisphosphonates have been widely used in the treatment of osteoporosis: alendronate, risedronate, ibandronate, and zoledronate.

The following paragraphs include brief descriptions of individual bisphosphonates, together with the results of clinical trials responsible for their approval for the treatment of osteoporosis, their antifracture efficacy in individual locations (Table II), type of osteoporosis (Table III), age group, and on-treatment fracture risk, and treatment duration required for the antifracture effect. This is to help select a formulation from the BP group for the given patient. Etidronate (the oldest BP) was not considered in this review, due to the fact that it is practically no longer used [2, 3].

\section{Alendronate}

Alendronate $(\mathrm{AL})$ is an amino-BP with no detrimental effect on bone mineralization. AL has been shown to prevent postmenopausal loss of bone mass in women under 60 years old without osteoporosis [9]. Three-year administration of $10 \mathrm{mg} /$ day $\mathrm{AL}$ in women with low bone mass (T-score <-2.0) and at least one previous vertebral compression fracture resulted in a significant (by $55 \%$ clinically and by $47 \%$ radiologically) reduction in the relative risk of new vertebral fractures, as well as wrist and hip fracture (by 51\%) [10]. Another clinical study in women with low bone mass ( $T$-score $<-2.0)$ and no

Table III. Bisphosphonates approved for the treatment of osteoporosis (indications)

\begin{tabular}{|lccc|}
\hline Bisphosphonates & $\begin{array}{c}\text { Postmenopausal } \\
\text { women }\end{array}$ & $\begin{array}{c}\text { Men } \\
\text { Alendronate }\end{array}$ & $\begin{array}{c}\text { Glucocorticoid- } \\
\text { induced } \\
\text { osteoporosis }\end{array}$ \\
\hline Risedronate & + & + & + \\
\hline Ibandronate & + & + & + \\
\hline Zoledronic acid & + & & \\
\hline
\end{tabular}


prior osteoporotic vertebral fractures demonstrated a significant relative risk reduction (by 53\%) of new vertebral fractures, however, hip fracture risk reduction (by 56\%) was statistically significant only in the subpopulation of women whose bone mass met WHO's diagnostic criteria of osteoporosis (T-score $<-2.5)$ [11]. Alendronate assessments yielded positive results also in studies on the treatment of osteoporosis in men, resulting in a statistically significant increase in bone mass and reduced incidence of vertebral fractures [12]. Similar results were achieved with $\mathrm{AL}$ administration in women and men receiving prolonged corticoid therapy in comparison to those receiving calcium and vitamin D [13].

The increase in bone mass and bone turnover inhibition resulting from a 70-mg weekly dose of alendronate are comparable to those achieved with a 10-mg daily dose. Increasing the time interval between consecutive doses improves long-term acceptance of treatment and considerably facilitates the treatment of osteoporosis [14].

In Poland, AL has been approved for prevention and treatment of osteoporosis in men at $10 \mathrm{mg}$ daily and $70 \mathrm{mg}$ weekly, osteoporosis in postmenopausal women, and $\mathrm{GIO}$.

\section{Risedronate}

Risedronate (RS) is an amino-BP with a heterocyclic side chain (R2) with no detrimental effects on bone mineralization. As part of clinical studies, women from their fifth postmenopausal year till the age of 85, with two or more previous vertebral fractions or one previous vertebral fraction and low bone mass in the lumbar spine or femoral neck ( $T$-score < 2.0), were administered risedronate at $2.5 \mathrm{mg} /$ day initially and, after one year, the dose was increased to $5 \mathrm{mg}$ /day. After only 6 months, there was an increase in BMD values in the spine and femoral neck. After 3 years of treatment, the relative risk of new fractures in women with at least two previous vertebral fractures and those with one previous vertebral fracture decreased by $49 \%$ and $41 \%$ (by up to $65 \%$ after one year), respectively, and the risk of extra-vertebral fractures decreased by $39 \%$ vs. baseline [15].

The effect of RS treatment on the risk of hip fracture in elderly women was assessed in randomized HIP studies. A 3-year follow-up of women aged 70-79 with the hip T-score $<-4.0$ or $<-3.0$ and the presence of extra-skeletal clinical risk factors for fractures revealed a reduced risk of hip fractures by $30 \%$. However, no reduction in the risk of hip fractures was observed in women enrolled to the HIP study solely on the basis of their risk factors but without low BMD. This suggests the need for RS treatment only in women with low bone mass [16].
Previous studies on the use of RS revealed that its antifracture effect persists for at least 7 years. Moreover, RS at $35 \mathrm{mg}$ administered weekly to women who had been treated for the previous 2 years with RS at $5 \mathrm{mg}$ daily, showed a similar response in terms of BMD values, bone formation and bone resorption markers (which suggests similar antifracture efficacy), a similar safety profile, but a greater comfort of administration. This weekly dose was also shown to be effective in the treatment of GIO and osteoporosis in men. These findings were the basis for introducing this dose to osteoporosis treatment options [17].

Risedronate has been approved in Poland for the prevention and treatment of osteoporosis in postmenopausal women, in men, and in patients with GIO at both $5 \mathrm{mg} /$ day and $35 \mathrm{mg} /$ week. Risedronate dosage at $150 \mathrm{mg}$ once a month is awaiting approval.

\section{Ibandronate}

Ibandronate (IB) used daily $(2.5 \mathrm{mg})$ reduces the risk of vertebral fractures by $50-60 \%$, and its effect on the incidence of fractures in other sites was demonstrated only in a post hoc analysis in women with baseline $T$-score $<-3.0$ [18]. Comparative studies indicated non-inferiority of oral $150 \mathrm{mg}$ monthly ibandronate vs. daily ibandronate in terms of BMD increase and bone turnover biomarker reduction. This allowed for this dosage to be approved for the treatment of osteoporosis in postmenopausal women [19]. An intravenous form of the drug ( $3 \mathrm{mg}$ ) administered once every 3 months was similarly approved (based on studies comparing the use of ibandronate via intermittent intravenous infusions vs. daily oral doses) [4].

\section{Zoledronate}

A study in postmenopausal women with osteoporosis and BMD T-score of $<-2.5$ or $T$-score $<-1.5$ and previous vertebral fractures conducted to evaluate the efficacy of $5 \mathrm{mg}$ zoledronic acid infusion administered once a year for 3 years, revealed a reduced incidence of vertebral fractures (by $70 \%$ ), and that of other fractures (by $40 \%$ ) [20]. A reduced incidence of vertebral fractures (by $60 \%$ ) was observed already at 12 months, and the risk of other fractures was reduced within 24 months. Moreover, the HORIZON study showed a $28 \%$ reduction in the risk of post-fracture mortality [21]. This study has become the basis for zoledronate approval for the treatment of osteoporosis in postmenopausal women. Additionally, studies showed that zoledronate reduced the number of new fractures in men and in patients with $\mathrm{GIO}$, which was the basis for its approval for use in these clinical indications [22, 23]. 


\section{Bisphosphonate safety profile}

Data on BP side effects come not only from RCTs but also from post-marketing pharmacovigilance reports and case reports collected after the process of registration has been concluded. As BPs have been used in clinical practice for years (alendronate for 18 years, risedronate for 13 years, ibandronate: oral for 8 years, intravenous for 7 years, zoledronate for 6 years), it is safe to say that BPs are the most thoroughly researched group of drugs used in osteoporosis treatment and that their general safety profile is favorable.

Side effects of BPs may affect the bone tissue as well as other organs (extra-skeletal side effects).

\section{Extra-skeletal side effects}

Oral BPs cause mild gastrointestinal dysfunction and, rarely, esophagitis. Such mild side effects, often not requiring treatment discontinuation, were observed in 1 out of 100 people treated with BP as part of osteoporosis phase III clinical studies of up to 3 years' duration. These symptoms occur more often with daily administration of first-generation BPs and are associated mainly with not following the protocol-recommended dosing regimen; much more rarely, with the use of amino-BPs as well as with weekly or monthly drug administration [24].

Intravenous BPs may cause a transient acute phase reaction with fever, myalgia, and osteodynia. Approximately $10-30 \%$ of patients receiving their first infusion of nitrogen-containing BPs develop an acute inflammatory reaction. The incidence of such reactions decreases by over a half following each subsequent infusion (the HORIZON study demonstrated that the incidence of acute phase reactions dropped to $2.8 \%$ after the third infusion). Acute phase reactions are believed to be the result of pro-inflammatory cytokine production by circulating B-cells. Administration of antihistamines or antipyretics may reduce the incidence and severity of these symptoms in susceptible patients [25].

There have been reports of the increased risk of atrial fibrillation (AF) in women receiving zoledronic acid (HORIZON study), as well as those receiving alendronate (a post hoc analysis of data from the FIT study). These findings raised doubts as to BP safety, especially in the elderly, whose most common arrhythmia is AF (the incidence of AF doubles with each decade of life after the age of 55 years and peaks between the age of 85 and 94). It is worth emphasizing that other comparative population studies failed to demonstrate any correlation between BP administration and increased incidence of AF. Having analyzed current study results, the Food and Drug Administration (FDA) did not confirm AF to be a BP-related side effect [24-26].

\section{Skeletal side-effects}

Recent years have seen an increased interest in detrimental effects of BP on bones.

Mandibular necrosis (osteonecrosis of the jaw). Nearly all cases (94\%) of mandibular and maxillary necrosis have been observed in patients with malignant tumors, receiving high doses of intravenous pamidronate or zoledronate. The incidence of this complication in patients with osteoporosis receiving oral and intravenous BPs is very low (between 1/10,000 and 1/100,000 of cases), without any causal relationship of this complication and the use of BPs having ever been confirmed. However, for the sake of prevention, a complete elimination of any foci of infection in the oral cavity is recommended in the period preceding BP therapy [24, 27].

Atypical femoral shaft fractures. Recent years have seen an increased number of publications on atypical femoral fractures as complications of long-term BP treatment. Such fractures are very rare. Based on large pre-marketing clinical studies FIT (alendronate) and HORIZON (zoledronate) and their post-marketing extensions: FLEX (a 10-year extension of the FIT study) and HORIZON-PET (a 3-year extension of the HORIZON study), the estimated incidence of such fractures is approximately 2.3/10,000 patient-years, however, there are no accurate epidemiological data to collaborate these figures $[24,28]$. Extensive information as to the definition, course, as well as clinical and radiological manifestations can be found in a report by the American Society for Bone and Mineral Research (ASBMR) [29].

A femoral shaft fracture is considered to be atypical if located in any part of the femoral shaft (distally to the lesser trochanter, and proximally to the intercondylar fossa, non-traumatic in nature or following a minor trauma (e.g. fall from standing height), with radiological evidence consistent with a stress fracture. Atypical fractures are often preceded by a dull, persistent prodromal pain in the groin or thigh of many weeks' or months' duration. According to ASBMR, radiological evidence of an atypical fracture is characterized by (major features): transverse or short oblique orientation (involving only the lateral cortex). Complete fractures extend through both cortices and may be associated with a medial spike. Additional features of an atypical femoral fracture: absence of comminution, local periosteal reaction of the lateral cortex, diaphyseal cortical thickening. An ASBMR report, compiled following an analysis of reported cases, listed the following conditions and drugs increasing the risk of atypical femoral fracture: long-term BP treatment, osteopenia, vitamin D deficiency (< $20 \mathrm{ng} / \mathrm{ml}$ ), rheumatoid arthritis, hypophosphatasia, the use of other antiresorptive drugs (hydrochlorothiazide, raloxifene, calcitonin, denosumab), GCs, and proton pump inhibitors. 


\section{How long should bisphosphonates be used?}

The safe BP treatment duration has not been precisely established. Treatment duration depends mainly on initial BMD values and the risk of osteoporotic fracture. The ASBMR report [29] stated that the mean duration of BP therapy preceding atypical fracture was 7 years, whereas a paper by Giustii [30] established that time at 5 years. With such a long (over 5 -year) use of BPs in osteoporosis treatment, the need for treatment continuation must be assessed occasionally (at least once a year), given the risk-to-benefit ratio (in each patient individually). Patients must be advised to report any thigh, hip, or groin pain during their BP treatment. Each patient presenting with such symptoms should be evaluated for an incomplete femoral fracture [29].

\section{Bisphosphonate drug holiday}

Considering recent reports on BP side effects during long-term osteoporosis therapy, the question emerges: for how long can these drugs be safely discontinued ('drug holiday'). Safely means that during such 'drug holiday' there would be no significant reduction in BMD or increase in the risk of a new fracture. Based on BMD analysis and the number of new vertebral fractures in extended, randomized studies: FLEX [31] (in female patients; after 5-year alendronate treatment the treatment was continued or switched to placebo for the subsequent 5 years) and HORIZON-PFT [32] (after 3-year treatment with zoledronic acid female patients continued their treatment or received placebo for another 3 years), a 5-year 'holiday' in the treatment with alendronate and a 3-year 'holiday' in the treatment of zoledronic acid resulted in no BMD reduction, and the number of new vertebral fractures did not increase in comparison to that in the placebo group. These data suggest the safety of a 5-year 'holiday' in the use of alendronate, and a 3-year 'holiday' in the use of zoledronic acid in women with postmenopausal osteoporosis.

Nonetheless, the decision to discontinue treatment should be made by the physician following fracture risk reassessment, and according to the patient's preferences. For this purpose a BMD assessment of the lumbar spine or femoral neck may be conducted. If the $T$-score is $>-2.5$ and there have been no new vertebral fractures (low fracture risk), the therapy may be discontinued. If the $T$-score stays below -2.5 or a new vertebral fracture occurs (high fracture risk), the therapy should be continued for another 5 or 3 years, in the case of alendronate or zoledronate, respectively [33]. We would like to emphasize that 'drug holiday' duration was assessed only in cases of long-term alendronate and zoledronate use and only in the group of postmenopausal women with osteoporosis. Therefore, until the appropriate studies have been conducted, there should be no extrapolation of data to include younger males and females, nor treatment with other BPs.

Despite a BP treatment of osteoporosis according to indications with a maintained good level of patient cooperation, a new fracture may still occur. In case a new fracture or a BMD loss greater than the least significant change vs. baseline occurs after 12 months of therapy, Polish experts consider this to be evidence of a lack of BP efficacy, which should lead to a change in the treatment method.

\section{Conclusions}

Large, randomized 3-4-year studies revealed the group of amino-BPs to be effective in reducing the risk of fractures in postmenopausal patients with osteoporosis, and some of these drugs to be also effective in osteoporosis in men and in patients with GIO. Thus, BPs have been considered to have a good safety profile. The widespread, long-term use of BPs (often exceeding the duration of clinical studies conducted for the purpose of study drug approval) in clinical practice as well as constant monitoring for side effects indicate a possibility of previously unknown complications occurring during the over-5-year-long treatment. These may include mandibular necrosis, atypical fractures, etc. Due to the known evidence of antifracture effect of alendronate, risedronate, and zoledronate, persisting after treatment discontinuation, a 'drug holiday' after 5 years of treatment with these BPs is justifiable. The decision to discontinue treatment should be made for each patient individually, based on fracture risk reassessment and another BMD measurement. A high fracture risk and low BMD ( $T$-score $<-2.5)$ indicates the need to continue treatment, whereas a low fracture risk with BMD T-score of $>-2.5$ allows for a few year-long 'holiday' in the use of BPs (benefits outweigh the risk). The duration of such 'drug holiday' in the case of alendronate has been specified as 5 years; and in the case of zoledronic acid - 3 years. Drug holiday duration has not yet been assessed for other amino-BPs used in osteoporosis treatment. Moreover, the existing evidence as to antifracture efficacy and safety of BPs in children and young adults (especially in women of childbearing potential) has been inadequate, which resulted in a lack of approval for BP use in these age groups. Therefore, all suggestions presented in this article regarding: clinical trial results (which led to BP approval for the treatment of osteoporosis), literature safety data on long-term use of BPs, and the indicated 'holiday' during long-term therapy refer to postmenopausal women. These suggestions are to help in both 
the selection of a specific amino-BP for the treatment of osteoporosis and the decision on treatment duration in the given patient.

The authors declare no conflict of interest.

\section{References}

1. Kanis JA, Burlet N, Cooper C, et al.; European Society for Clinical and Economic Aspects of Osteoporosis and Osteoarthritis (ESCEO). European guidance for the diagnosis and management of osteoporosis in postmenopausal women. Osteoporos Int 2013; 19: 399-428.

2. Głuszko P, Lorenc R. Osteoporoza pierwotna i wtórna. Wskazówki postępowania dla reumatologów. Reumatologia 2012 50: 370-377.

3. Marcinowska-Suchowierska E, Czerwiński E, Badurski J. Leczenie farmakologiczne osteoporozy. In: Osteoartrologia kliniczna. Badurski J (ed.). Termedia, Poznań 2011; 147-175.

4. Body JJ, Bergmann P, Boonen S, et al. Evidence-based guidelines for the pharmacological treatment of postmenopausal osteoporosis: a consensus document by the Belgian Bone Club. Osteoporos Int 2010; 21: 1657-1680.

5. Dziedzic-Gocławska A, Kamiński A. Mechanizmy działania bisfosfonianów na komórki tkanki kostnej. Terapia 2001; 11: 23-27.

6. Kavenagh KL, Guo K, Dunford JE, et al. The molecular mechanism of nitrogen-containing bisphosphonates as antiosteoporosis drugs. Proc Natl Acad Sci U S A 2006; 103: 7829-7834.

7. Drake TD, Clarke BL, Khosla S. Bisphosphonates: mechanism of action and role in clinical practice. Mayo Clin Proc 2008; 83: 1032-1045.

8. Miller PD, Jamal SA, Evenepoel P, et al. Renal safety in patients treated with bisphosphonates for osteoporosis: A review. J Bone Miner Res 2013; 28: 2049-2059.

9. Hosking D, Chilvers CE, Christiansen C, et al. Prevention of bone loss with alendronate in postmenopausal women under 60 years of age. Early Postmenopausal Intervention Cohort Study Group. N Engl I Med 1998; 338: 485-492.

10. Black DM, Cummings SR, Karpf DB, et al. Randomized trial of effect of alendronate on risk of fracture in women with existing vertebral fractures. Fracture Invention Trial Research Group. Lancet 1996; 348: 1535-1541.

11. McClung M, Clemmesen B, Daifotis A, et al. Alendronate prevents postmenopausal bone loss in women without osteoporosis. A double blind, randomized, controlled trial. Alendronate Osteoporosis Prevention Study Group. Ann Intern Med 1998; 128: 253-261.

12. Orwoll E, Ettinger $M$, Weiss $S$, et al. Alendronate for the treatment of osteoporosis in men. N Engl J Med 2000; 343: 604-610.

13. Adachi JD, Saag KG, Delmas PD, et al. Two-year effect of alendronate on bone mineral density and vertebral fracture in patients receiving glucocorticoids: a randomized, double-blind, placebo-controlled extension trial. Arthritis Rheum 2001; 44: 202-211.
14. Schnitzer T, Bone HG, Crepaldi G. Therapeutic equivalence of alendronate $70 \mathrm{mg}$ once-weekly and alendronate $10 \mathrm{mg}$ daily in the treatment of osteoporosis. Aging (Milano) 2000; 12: 1-12.

15. Watts NB, Josse RG, Hamdy RC, et al. Risedronate prevents new vertebral fractures in postmenopausal women at high risk. J Clin Endocrinol Metab 2003; 88: 542-549.

16. McClung MR, Geusens P, Miller PD, et al. Effect of risedronate on the risk of hip fracture in elderly women. Hip Intervention Program Study Group. N Engl J Med 2001; 344: 333-340.

17. Brown JP, Kendler DL, McClung MR, et al. The efficacy and tolerability of risedronate once a week for the treatment of postmenopausal osteoporosis. Calcif Tissue Int 2002; 71: 103-111.

18. Chesnut III CH, Skag A, Christiansen C, et al. Oral Ibandronate Osteoporosis Vertebral Fracture Trial in North America and Europe (BONE). Effects of oral ibandronate administered daily or intermittently on fracture risk in postmenopausal osteoporosis. J Bone Miner Res 2004; 19: 1241-1249.

19. Reginster JY, Adami S, Lakatos P, et al. Efficacy and tolerability of oncemonthly oral ibandronate in postmenopausal osteoporosis: 2 year results from the MOBILE study. Ann Rheum Dis 2006; 65: 654-661.

20. Black DM, Delmas PD, Eastell R, et al. Once-yearly zoledronic acid for treatment of postmenopausal osteoporosis. N Engl J Med 2007; 356: 1809-1822.

21. Lyles KW, Colón-Emeric CS, Magaziner JS, et al. The HORIZON Recurrent Fracture Trial: Zoledronic acid and clinical fractures and mortality after hip fracture. N Engl J Med 2007; 357 : 1799-1809.

22. Reid DM, Devogelaer JP, Saag K, et al. Zoledronic acid and risedronate in the prevention and treatment of glucocorticoid-induced osteoprosis (HORIZON): a multicentre, double-blind, double-dummy, randomised controlled trial. Lancet 2009; 373: 1253-1263.

23. Rao SS, Budhwar N, Ashfaque A. Osteoporosis in Men. Am Fam Physician 2010; 82: 503-508.

24. Ro C, Cooper O. Bisphosphonate drug holiday: choosing appriprate candidates. Curr Osteoporos Rep 2013; 11: 45-51.

25. Mc Clung M , Harris ST, Miller PD, et al. Bisphosphonate therapy for osteoporosis: benefits, risks and drug holiday. Am J Med 2013; 126: 13-20.

26. Suresh E, Paziananas M, Abrahamsen B. Safety issues with bisphosphonate therapy for osteoporosis. Rheumatology (Oxford) 2014; 53: 19-31.

27. Rizzoli R, Burlet N, Cahall D, et al. Osteonecrosis of the jaw and bisphosphonate treatment for osteoporosis. Bone 2008; 42: 841-847.

28. Black DM, Kelly MP, et al. Bisphosphonates and fractures of subtrochanteric or diaphyseal femur. N Engl J Med 2010; 362: 1761-1771

29. Shane E, Burr D, Ebrling PR, et al. Atypical subtrochanteric and diaphyseal femoral fractures: report of a task force of American Society for Bone and Mineral Research. J Bone Miner Res 2010; 11: 2267-2294.

30. Giusti A, Hamdy NA, Papapoulos SE, et al. Atypical fractures of the femur and bisphosphonate therapy: a systematic review of case/case series studies. Bone 2010; 47: 169-180.

31. Black DM, Schwartz AV, Ensrud KE, et al. Effects of continuing or stoping alendronate after 5 years of treatment; the Frac- 
ture Intervention Trial Long-Term Extension (FLEX): a randomized trial. JAMA 2006; 296: 2927-2938.

32. Black DM, Reid IR, Boonen S, et al. The effect of 3 versus 6 years of zolendronic acid treatment of osteoporosis: a randomized extension to HORIZON-Pivotal Fracture Trial (PFT). J Bone Miner Res 2012; 27: 243-254.

33. Black DM, Bauer DC, Schwartz AV, et al. Continuing Bisphosphonate Treatment for Osteoporosis - For Whom and for How Long? N Engl J Med 2012; 366: 2051-2053. 